\title{
THE EFFECT OF BEHAVIORAL AND PERFORMANCE ASPECTS OF EDUCATOR ACCOUNTANTS ON THE ACCOUNTING STUDENTS' COMPETENCE
}

\author{
Denny Kurnia* \\ Universitas Serang Raya \\ Raya Serang-Cilegon Rd., Serang \\ Indonesia 42162 \\ dennyrahmadhiya@gmail.com
}

\begin{abstract}
This study aims to determine the effect of behavioral and performance aspects of educator accountants on the competence of accounting students at universities throughout Banten Province. The method used is descriptive and associative quantitative. The results of the descriptive analysis showed that the behavioral aspect of the perception dimension variable had the highest average value, the lowest motivation dimension. The variable of educator accountants' performance of the collaboration dimension had the highest average value and the lowest of higher education Tridharma output quality dimension. The variable of accounting students' competence in the dimension of learning to live together has the highest average value, and the dimension of learning to understand is the lowest. The results of the associative analysis were obtained simultaneously that the behavioral and performance aspects of educator accountants affect the competence of accounting students.
\end{abstract}

Keywords: Behavioral Aspects; Educator Accountant Performance; Accounting Students' Competence

\section{ABSTRAK}

Penelitian ini bertujuan untuk mengetahui pengaruh aspek keperilakuan dan kinerja akuntan pendidik terhadap kompetensi mahasiswa akuntansi di Perguruan Tinggi se-Provinsi Banten. Metode yang digunakan adalah kuantitatif deskriptif dan asosiatif. Hasil analisis deskriptif diperoleh bahwa pada variabel aspek keperilakuan dimensi persepsi memiliki nilai rata-rata tertinggi, dimensi motivasi terendah. Variabel kinerja akuntan pendidik dimensi kerja sama memiliki nilai rata-rata tertinggi, dimensi kualitas output tridarma perguruan tinggi terendah. Variabel kompetensi mahasiswa akuntansi dimensi learning to live together memiliki nilai ratarata tertinggi, dimensi learning to understand terendah. Hasil analisis asosiatif diperoleh secara simultan aspek keperilakuan dan kinerja akuntan pendidik berpengaruh terhadap kompetensi mahasiswa akuntansi.

Kata Kunci: $\quad$ Aspek Keperilakuan; Kinerja Akuntan Pendidik; Kompetensi Mahasiswa Akuntansi

JEL Classification: A22; I23

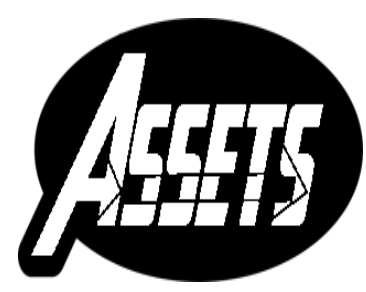

ASSETS

Jurnal Akuntansi dan Pendidikan

Vol. 10 No. 2

Page 111-122

Madiun, October 2021

p-ISSN: 2302-6251

e-ISSN: 2477-4995

Article History

Submitted:

February 17, 2020

Accepted:

October 15, 2021 


\section{INTRODUCTION}

It is developing the competence of accounting students as part of efforts to improve superior and competitive human resources. Competence is a characteristic that underlies a person to achieve high performance in his work (Hariani \& Sudrajat, 2016). According to UNESCO the competence as the development of education pillars, that the competencies achieved by students in the educational process are the ability to learn to know (learning to know), the ability to learn to understand (learning to understand), the ability to learn to do (learning to do), the ability to learning to live together (learning to live together), the ability to learn to be yourself (learning to be). In the current era of the 4.0 industrial revolution and towards the 5.0 industrial revolution, the development of competence and professionalism of the workforce is highly expected, especially for workers who are equipped with international professional certifications. It is also intended for the profession of accountants.

The phenomenon occurs in the current era of globalization, where foreign workers can enter and work in Indonesia, especially foreign workers who work as accountants. Foreign accountants are allowed to practice in Indonesia without being affiliated with a local partner (Mardjono \& Solikhan, 2014). Not a few graduates of accounting study programs experience confusion when faced with the real world of work and work that does not follow the field of study they are engaged. Accounting graduates who work according to their field are only 33\%(Murniasih \& Purnamawati, 2015). accounting students in Indonesia must be equipped with professional accounting competencies to have internationally accepted qualifications and competencies in terms of professional skills, so they can compete with foreign workers who work as accountants (Wirianata, 2017).

Improving the behavioral and performance aspects of educator accountants can increase the competence of accounting students expected by users, namely the business and industrial world. Such as providing training for inexperienced educator accountants to improve teaching skills, research results, and the community service of educator accountants (Ismail, 2018). Educator accountants are accountants in charge of accounting education, conducting research and development of accounting, teaching, arranging accounting education curriculum in higher education (Indonesian Institute of Accountants). According to Ismail, Hasan, \& Musdalifah (2018), the quality or competence of teachers or lecturers can reflect the low quality of national education and the low competitiveness of the community.

The application of behavioral accounting to accounting students is where higher education produces professional human resources who are expected to meet the needs of the existing market (Sarmigi \& Andriadi, 2019). Psychology, sociology, and social psychology are the main pillars of behavioral science. According to Siegel and Marconi in Muliawati, the behavioral aspects of psychology and social psychology consist of 5 aspects of attitude, motivation, perception, learning, and personality (Muliawat, 2012). Meanwhile, Lubis in Purnama has two additional aspects concerning behavioral aspects, namely attitudes, motivations, perceptions, values, learning, personality, and emotions (Purnama \& Azizah, 2019).

Dimensions of behavioral aspects to be observed consist of: attitudes, motivations, perceptions, and emotions. Attitude is the tendency of a person's pleasant and unpleasant statements to reflect how he feels about people, objects, or events in his environment (Wibowo, 2014). Motivation is an urge to act on a series of processes of human behavior by considering the direction, intensity, and persistence in achieving the goals (Wibowo, 2014). Perception is a process that allows us to organize 
information and interpret impressions on the surrounding environment (Wibowo, 2014). Emotions are intense feelings directed at someone or something (Wibowo, 2014).

Performance is the success of people to carry out the works, responsibilities, skills to meet expectations and standard measures (Mukmin \& Wulansari, 2017). The performance of educator accountants in carrying out Tridharma activities of higher education can increase students' understanding of accounting science (Suryanti \& Arfah, 2019). The performance dimensions of the educator accountant consist of: (1) the quality of the output of the Tridharma of higher education, namely the level where the final achievement meet the goals expected by the agency, (2) the quantity of the output of the Tridharma of higher education, namely the amount produced in terms of the number of activities produced, (3) punctuality, namely the level of activity of completing the higher education Tridharma at the specified time, and (4) cooperation/cooperative attitude (Cooperation with other work) is the condition of each educator accountant, whether helping or hindering his co-workers (Suryanti \& Arfah, 2019).

Aspects of behavior and performance of educators accountant play a vital role in improving accounting students' competence. Several previous researchers stated that universities, in this case, educators accountants have a role in designing their courses (curriculum) to be easily understood by their students (Laksmi \& Febrian, 2018). In the student's perception that the ethics of educator accountants, which contains the competence and behavior of educator accountants, have an essential role for accounting students (Meilisa \& Ludigdo, 2010). The vital role of educator accountants in implementing learning methods is to motivate accounting students to improve their competence (Harris \& Mardiyati, 2013). Simultaneously intellectual intelligence, emotional intelligence, spiritual intelligence, and learning behavior positively affect accounting understanding (Syamsuddin, 2019). Therefore, educator accountants are expected to be able to improve the quality of learning in order to be able to produce accounting graduates following the demands of the labor market (Riczqi, Putri, \& Harto, 2012).

This research is updated from previous research to enrich research results and provide solutions to accounting student competency problems. Previous research examined accounting graduates according to user needs, accounting understanding, learning quality, students' learning achievement, accounting student understanding. Meanwhile, this study examines educator accountants, especially their performance and behavioral aspects, which have a vital role in increasing the competence of accounting students. Therefore, this study aims to determine and contribute to the model of behavioral and performance aspects of educator accountants to improve the accounting students' competencies.

\section{METHOD}

The type of research used in this study is quantitative research. The research method used is descriptive and associative. This study aims to examine whether there is an influence between behavioral and performance aspects of educator accountants on the accounting students' competencies.

The population in this study is the number of accountants educators at universities in Banten Province, amounting to 160. The method of determining the sample used is accidental sampling/convenience sampling is a non-probability sampling technique where the subject is chosen because of accessibility. The number of 
samples used was 45 samples from respondents who were selected and responded to the questionnaire results.

This research data is primary data obtained using a survey method through questionnaires distributed to educator accountants as respondents spread across various universities throughout Banten Province. The questionnaire used is from the theoretical concept developed into dimensions and indicators used as research instruments. The behavioral aspect variable consists of four dimensions with nine indicators. The educator accountant performance variable consists of four dimensions with nine indicators. The accounting students' competence variable consists of five dimensions with five indicators.

The data scale used is interval and uses a Likert scale with an interval of one to seven $(1-7)$. The questionnaire that was distributed beforehand has been tested for validity and reliability out of the sample. The distribution of the questionnaires was carried out using a google form so that the distribution of the questionnaires could be faster and more effective. This study's data analysis methods include validity and reliability tests, classical assumption tests, descriptive statistical analysis, and multiple linear regression tests using SPSS statistical software version 22.

\section{RESULT AND DISCUSSION}

The characteristics of the respondents obtained from the questionnaire results can be seen in Table 1. The characteristics of the sample of educator accountants who have functional lecturer positions are dominated by assistant professor positions $(44,5 \%)$ and instructor $(33,3 \%)$. In comparison, the last education of educator accountants is dominated by master's education $(82,2 \%)$ and doctoral education $(17,8 \%)$.

Table 1. Characteristics of Respondents

\begin{tabular}{lrr}
\hline \multicolumn{1}{c}{ Characteristics of Respondents } & Amount & Percentage \\
\hline A. Functional & 3 & $6,7 \%$ \\
1. Teaching Staff (Does not have a functional & & \\
$\quad$ position & 15 & $33,3 \%$ \\
2. Instructor & 20 & $44,5 \%$ \\
3. Assistant Professor & 6 & $13,3 \%$ \\
4. Associate Professor & 1 & $2,2 \%$ \\
5. Professor & & \\
B. Current education & 37 & $82,2 \%$ \\
1. Second degree (S-2) & 8 & $17,8 \%$ \\
2. Third-degree (S-3) & & \\
\hline
\end{tabular}

Based on table 2, the educator accountant has an excellent perception of the profession and works as an educator accountant with the statement that the profession as an educator accountant is a noble and exciting job. This perception dimension has the highest average value of 6,533 compared to other dimensions; this perception dimension is supported by indicators stating that the profession as an educator accountant is a noble profession with the highest average value of 6,6667 compared to other indicators on the behavioral aspect variable.

However, educator accountants are less motivated, either from leadership motivation or the reward and punishment system. Therefore, the motivation dimension has the lowest average of 5,733 compared to other behavioral aspect 
variables. The indicator states "the motivation of the leader who always directs the duties and functions as a lecturer" has the lowest average value of 5,6444. It shows that it is necessary to increase the motivation of educator accountants, especially motivation by the leadership towards educator accountants.

\section{Table 2. Descriptive of Behavioral Aspect Variables}

\begin{tabular}{lll}
\hline Statement & N Sum Mean \\
\hline Attitude Dimension
\end{tabular}

Attitude Dimension

1. Educators accountants always develop knowledge and carry out teaching to students as well as possible.

$45 \quad 292,00 \quad 6,4889$

2. Educators accountants always conduct research related to accounting.

$45 \quad 275,00 \quad 6,1111$

3. Educators accountants always do community service related to accounting.

$45 \quad 255,00 \quad 5,6667$

Motivation Dimension

4. Educators accountants feel helped by leaders who always direct their duties and functions as lecturers

$45 \quad 254,00 \quad 5,6444$

5. Educators accountants are motivated by a system of rewards and punishments for performance.

$45262,00 \quad 5,8222$

Perception Dimension

6. The profession of an educator's accountant is a noble job.

$45300,00 \quad 6,6667$

7. The profession as an educators accountant is exciting.

$45288,00 \quad 6,4000$

Emotion Dimension

8. The profession as an educator's accountant aspires.

$45 \quad 257,00 \quad 5,7111$

9. The profession as an educators accountant is very happy.

$45 \quad 289,00 \quad 6,4222$

Table 3. Descriptive Variables of Educator Accountant Performance

\begin{tabular}{lrrr}
\hline Statement & N & Sum & Mean \\
\hline $\begin{array}{l}\text { Dimensions of Higher Education Tridharma Output Quality } \\
\text { 1. The material presented to students follows the KKNI }\end{array}$ & 45 & 277,00 & 6,1556 \\
$\begin{array}{l}\text { curriculum. } \\
\text { 2. Publish research articles in reputable published journals. }\end{array}$ & 45 & 260,00 & 5,7778 \\
$\begin{array}{l}\text { 3. Publish community service articles in reputable published } \\
\text { journals. }\end{array}$ & 45 & 215,00 & 4,7778 \\
$\begin{array}{l}\text { Dimensions of Higher Education Tridharma Output Quantity } \\
\text { 4. The teaching load of courses each semester is 12 credits to }\end{array}$ & 45 & 266,00 & 5,9111 \\
$\begin{array}{l}\text { 16 credits } \\
\text { 5. Each year research at least once. }\end{array}$ & 45 & 274,00 & 6,0889 \\
6. Every year conduct community service at least once. & 45 & 280,00 & 6,2222
\end{tabular}

Dimensions of Punctuality in Implementing Tridharma of Higher

Education

7. Always on time and following the provisions of the number of meetings, in carrying out teaching activities

$45 \quad 280,00 \quad 6,2222$

8. Always on time in carrying out and completing research $\quad 45 \quad 263,00 \quad 5,8444$ 
KURNIA, D.

\begin{tabular}{llll}
\hline Statement & $\mathrm{N}$ & Sum & Mean \\
\hline $\begin{array}{l}\text { Dimensions of Cooperation/Cooperative Attitude } \\
\begin{array}{l}\text { 9. In carrying out the university's tri dharma activities, } \\
\text { collaborate with fellow lecturers }\end{array}\end{array}$ & 45 & 283,00 & 6,2889 \\
\hline
\end{tabular}

Based on table 3, the educator accountant's performance in carrying out the Tridarma activities of higher education, in collaboration with colleagues and lecturers, has an excellent performance. It is proven from the analysis results that these dimensions and indicators have the highest average value of 6,2889.

However, the performance of educator accountants regarding the quality of higher education Tridharma output is still low with an average value of 5,778, especially in the indicator of publishing articles for community service in reputable published journals, which have the lowest average value of 4,7778 compared to other indicators. It shows a need to improve the quality performance of higher education Tridharma outputs, especially in the publication of community service articles in published journals. Based on previous studies, several variables influence the performance of educator accountants, including intellectual intelligence, motivation, and job satisfaction (Akib \& Asni, 2016). The performance of educator accountants can also be improved through motivation and job satisfaction (Irwandi, 2016).

Table 4. Descriptive Variables of Accounting Student Competence

\begin{tabular}{|c|c|c|c|}
\hline Statement & $\mathrm{N}$ & Sum & Mean \\
\hline $\begin{array}{l}\text { 1. Accounting study program students have excellent } \\
\text { knowledge of accounting. }\end{array}$ & 45 & 256,00 & 5,6889 \\
\hline $\begin{array}{l}\text { 2. Accounting study program students have an excellent } \\
\text { understanding of accounting. }\end{array}$ & 45 & 246,00 & 5,4667 \\
\hline $\begin{array}{l}\text { 3. Students of the accounting study program have excellent } \\
\text { abilities to do the assigned accounting tasks. }\end{array}$ & 45 & 254,00 & 5,6444 \\
\hline $\begin{array}{l}\text { 4. Accounting study program students have excellent ability } \\
\text { to study and work together with friends to solve } \\
\text { accounting problems. }\end{array}$ & 45 & 258,00 & 5,7333 \\
\hline $\begin{array}{l}\text { 5. Students of the accounting study program have excellent } \\
\text { abilities to ask questions and provide opinions about } \\
\text { accounting material. }\end{array}$ & 45 & 255,00 & 5,6667 \\
\hline
\end{tabular}

Based on table 4, the competence of accounting students has an excellent ability to learn and work together with friends to solve accounting problems. The analysis results show that it has the most significant average value of 5,7333 compared to other indicators. However, students of the accounting study program do not have an excellent understanding of accounting. The analysis results show that it has the lowest average value of 5,4667 compared to other indicators. Therefore, from the analysis results, students of accounting study programs need to improve their understanding of accounting. There are several variables to improve the competence of accounting students, including that internship programs or practical work courses can improve the competence of accounting students (Ismail et al., 2018). The professionalism of educators accountants, emotional intelligence, and learning methods can also improve the competence of accounting students (Suryanti \& Arfah, 2019) 
The results of the validity and reliability test of the research instrument were declared valid and reliable. The instrument used is an instrument that has been declared valid and reliable. The unstandardized and standardized coefficients are used to interpret the coefficients of the independent variables. The results of the partial significance test (t-test) can be seen in table 5 .

Table 5. Hypothesis Test Results $t$

\begin{tabular}{llrrrr}
\hline & Model & Coefficient & Std. Error & t-statistics & Prob. Sig. \\
\hline 1 & (Constant) & 0,411 & 4,157 & 0,099 & 0,922 \\
& AK & 0,365 & 0,104 & 3,493 & 0,001 \\
& HOOD & 0,146 & 0,085 & 1,719 & 0,093 \\
\hline
\end{tabular}

a. Dependent Variable: KMA

b. Significance at $=5 \%$ follows:

The results of this analysis can be seen in the regression equation model as $\mathrm{KMA}=0.411+0.365 \mathrm{AK}+0.146 \mathrm{KAP}+\mathrm{e}$ .(Equation 1)

Unstandardized beta coefficients from the output of SPSS version 22 produce a regression model of the two independent variables. The behavioral aspect variable (AK) produces a t-count value of 3,493, more significant than the ttable value of 2,014 and the significance probability value of Prob. Sig of 0,001 is smaller than the significance level $(a=0,05)$, which means that the behavioral aspect of the educator accountant has a significant influence on the competence of accounting students. While the value of unstandardized coefficients $(\beta)$ is 0,365 , this means that every one-unit increase in the behavioral aspect of educator accountants can increase by 0,365 one unit of accounting student competence.

The educator accountant performance variable (KAP) produces a tcount of 1,719, which is smaller than the t-table value of 2,014 and the significance probability value of Prob. Sig is 0,093 , which is greater than the significance level $(\alpha=0.05)$, which means that the performance of the educator accountant does not significantly influence the competence of accounting students. So the value of unstandardized coefficients $(\beta)$ of educator accountants' performance is 0,146 . It is not meant to increase the competence of accounting students.

Table 6. Hypothesis Test Results in F

\begin{tabular}{lrrr}
\hline Model & $\begin{array}{r}\text { Coefficient } \\
\text { Terminated }\end{array}$ & F-statistics & Prob. Sig. \\
\hline KMA & 0,522 & 22,977 & $0,000 \mathrm{a}$
\end{tabular}

a. Predictors: (Constant), KAP, AK

Source: Research findings

Based on Table 6, statistical results indicate that the contribution of variations in the influence of behavioral aspects and performance of educator accountants together (simultaneously) on the competence of accounting students is $52,2 \%$. In comparison, the remaining $47,8 \%$ is caused by reasons other than model. 
The ANOVA test statistic with a significant probability of 0,000 is less than 0,05 , so the regression model can be used to predict the simultaneous (simultaneous) effect between the behavioral aspects and the performance of educator accountants on the competence of accounting students.

\section{The Influence of Behavioral Aspects on the Competence of Accounting Students}

Behavioral aspects consisting of attitudes, motivations, perceptions, and emotions exist in a person, including an educator accountant. The dimensions of this behavioral aspect apply to a person whom others can feel. With the behavioral aspect of a good educator accountant, of course, it is expected to increase the competence of accounting students, namely the achievement of several abilities in the accounting field by students that must be possessed as a reference that these students have mastered the accounting material that has been given for their life in society related to the ability to learning to know (learning to know), the ability to learn to understand (learning to understand) the ability to learn to do (learning to do),

Based on the results of data analysis, accounting study program students have excellent ability to study and work together with friends to solve accounting problems, which is the indicator with the highest weight with an average value of 5,7333 , compared to other indicators in accounting student competence. Therefore, accounting educators are more directing accounting students to develop teaching by applying working together to solve accounting problems. It is in line with the statement that the creativity of students who follow the student-centered learning strategy is higher than that of students who follow the direct learning strategy (Ardian \& Munadi, 2015).

The role of the behavioral aspect to improve the competence of accounting students based on the results of data analysis can be described as follow. The influence of the behavioral aspect of the educator accountant has a coefficient value of 0,365 with a significance value of 0,01 , which is smaller than 0,05 . It means that the behavioral aspect of the educator accountant has a positive and significant influence on student competence. The indicator of the perception that profession as an educator accountant is a noble job, which is the indicator with the highest weighted value, the average value of 6,6667 compared to other indicators on the behavioral aspect of the educator accountant based on the results of this research data analysis.

The results of this study indicate the need for leadership attention to always direct the duties and functions as an educator accountant so that they are committed and have the competence to improve the competence of accounting students. The results of this study are in line with the statement that the role of accountants for commitment and competence together affects the professionalism of prospective accountants (Sawitri, 2017).

The better the attitudes, motivations, perceptions, and emotions related to the behavior of accountants educators, it will be able to increase the competence of accounting students both in terms of the ability to learn to know (learning to know), the ability to learn to understand (learning to understand) and the ability to learn to do (learning to understand), the ability to learn to live together (learning to live together), the ability to learn to be yourself (learning to be) in accounting. It is in line with the opinion that the quality of academics related to learning can produce competent accounting graduates, following the labor market demands (Riczqi et al., 2012). Quality is a person's ability. In accounting educator's attitudes, motivations, perceptions, and emotions related to the behavior of a good educator accountant are characteristics of a quality educator accountant. Opinion (Mardjono \& Solikhan, 2014) also mentioned that 
the professional commitment of accounting educators could improve the quality of accounting graduates.

College management and educator accountants are expected to pay attention to the behavioral aspects of educator accountants to develop knowledge in the field of accounting, improve research and serve the community. Higher education leaders can assign tasks to educator accountants and implement a system of rewards and punishments. According to Nahartyo's (2016) statement, accounting educators can adopt a broader behavioral perspective so that the outstanding value of accounting education can still be achieved and maintained. As accountants, educators must increase the perception that accounting educators are noble jobs, exciting and fun, to increase the competence of accounting students.

\section{The Effect of Educator Accountant Performance on Accounting Students' Competence}

The performance of an educator accountant can be measured based on the quality and quantity of the output of the tri dharma of higher education, the timeliness of the tri dharma of higher education, attendance at work, years of service that individual employees have undertaken, and cooperation/cooperative attitude. The role of the performance of educator accountants to improve the competence of accounting students is based on the results of data analysis that the effect of the performance aspect of educator accountants has a coefficient value of 0,146 with a significance value of 0,093 . It is more significant than 0,05 , which means that partially the performance of educator accountants does not affect the competence of accounting students. The results of this study are in line with the research of Suryanti \& Arafah, who stated that the professionalism of educator accountants partially did not affect students' accounting understanding.

The quality and quantity of the output of the tri dharma of higher education, the timeliness of the tri dharma of higher education, attendance at work, years of service, and cooperation/cooperative attitude cannot significantly increase the competence of accounting students in terms of relating to the ability to learn to know, the ability to learn to understand, the ability to learn to do, the ability to learn to live together, the ability to learn to be himself in accounting.

The results of this study are not in line with the opinion (Ismail et al., 2018), (Riczqi et al., 2012) as well as (Mardjono \& Solikhan, 2014). It is indicated because there are still research indicators that have low scores, namely the lack of publishing research articles and community service. There are still many available positions of educator accountants who have instructor positions as much as $33,3 \%$. The educational level of educator accountants is still dominated by the education level of S-2 as much as $82,2 \%$. The performance of educator accountants has not been maximally applied in the accounting learning system to students. The performance of educator accountants is still intended to improve the competence of educator accountants, not to maximize the competence of accounting students. Therefore, it is expected that higher education management and educator accountants can support and improve educational qualifications, publishing research articles and community service to improve the functional positions of educator accountants. Following the statement that educators and higher education accountants are expected to stimulate/increase the competence of educator accountants with a positive attitude towards the tasks carried out by carrying out their functions and positions (Mukmin \& Wulansari, 2017). 


\section{The Influence of Behavioral Aspects and Performance of Educator Accountants on} the Competence of Accounting Students

Aspects of behavior and performance of accountants educators simultaneously have a positive and significant influence on the competence of accounting students. It is evidenced from the results of statistical analysis of the $\mathrm{F}$ test with a significant probability of 0,000 (less than 0,05 ). Based on these results, the regression model can be used to predict the effect simultaneously between the behavioral aspect variables and the performance of educator accountants on the competence of accounting students. The contribution of variations in the influence of the behavioral aspect variables and the performance of educator accountants simultaneously on the competence of accounting students is $52,2 \%$, while the remaining $47,8 \%$ is caused by reasons other than this regression model, such as intellectual intelligence, emotional intelligence, spiritual intelligence,

The behavioral aspect of the educator accountant variable has a significant influence on accounting students' competence compared to the educator accountant performance variable. It is evidenced by the regression coefficient value of the behavioral aspect variable of 0,365, while the regression coefficient value of the educator accountant performance variable is 0,146 . Therefore, universities should provide a more significant portion in maintaining and increasing the values of the behavioral aspects of educator accountants without neglecting to increase the performance values of educator accountants to improve the competence of accounting students. The results of this study are in line with the results of the research of Laksmi \& Febrian (2018), Meilisa \& Ludigdo (2010); Harris \& Mardiyati (2013); and Riczqi, Putri, \& Harto (2012). They state that the behavioral and performance aspects of educator accountants have an essential role in increasing the competence of accounting students.

\section{CONCLUSION}

This study shows that the behavioral aspects and performance of educator accountants can simultaneously affect accounting students' competence. The behavioral aspect of educator accountants is a variable that has a dominant influence on the competence of accounting students. Increasing the aspects of attitudes, motivations, perceptions, and emotions of educator accountants can increase the competence of accounting students. Likewise, it is hoped that by increasing the quality and quantity of the output of the Tridharma of Higher Education, the timeliness of the Tridharma of Higher Education, attendance at work, years of service, and the cooperative attitude of educator accountants can increase the competence of accounting students to learn to know.

This study has several limitations. Namely, it was only conducted at universities in Banten Province, so it cannot be generalized throughout Indonesia. In addition, this study applies descriptive and associative methods, which obtained data through a written questionnaire as primary data. It gives rise to a different perception of the respondent from the actual situation. Based on these limitations, it is recommended that further research should expand the research subject area. The Banten area covers a wide area, involving private universities and other state universities. Further research can also use secondary data in order to describe the actual conditions.

\section{REFERENCES}

Akib, M. Akib, M., \& Asni, N. (2016). Pengaruh Kecerdasan Intelektual Terhadap Kinerja Akuntan Pendidik Pada Jurusan Akuntansi Fakultas Ekonomi dan Bisnis 
Universitas Halu Oleo. Jurnal Ilmu Ekonomi \& Sosial, VII(1), 1-13.

Ardian, A., \& Munadi, S. (2015). Pengaruh strategi pembelajaran student-centered learning dan kemampuan spasial. Jurnal Pendidikan Teknologi Dan Kejuruan, $22,454-466$.

Hariani, D. S., \& Sudrajat, M. A. (2016). Analisis Pengaruh Kompetensi Aparatur Pemerintah Desa Terhadap Penggunaan Teknologi Accounting Information System Pada Desa-Desa Di Kabupaten Madiun. Assets Jurnal Akuntansi Dan Pendidikan, 5, 113-128.

Harris, L., \& Mardiyati, E. (2013). Atas Sistem Aplikasi Enterprise Resource Planning. Jurnal Akuntansi Multiparadigma (JAMAL), 4(1), 55-74.

Irwandi. (2016). Pengaruh Motivasi Terhadap Kepuasan Kerja dan Dampaknya Terhadap Kinerja Akuntan Pendidik (Dosen Akuntansi) (Studi Pada Perguruan Tinggi Swasta di Bandar Lampung). Jurnal Akuntansi \& Keuangan, 7(1).

Ismail, Hasan, \& Musdalifah. (2018). Pengembangan Kompetensi Mahasiswa Melalui Efektivitas Program Magang Kependidikan. Maspul Journal of Community Empowerment Jurnal Pengabdian Masyarakat Massenrempulu, 2(February), 817. https://doi.org/10.33487/edumaspul.v2i1.48

Ismail, T. (2018). Kesenjangan Harapan Keterampilan Yang Dimiliki Oleh Sarjana Akuntansi. Jurnal Riset Akuntansi Terpadu, 11(2), 138-147. https:// doi.org/10.35448/jrat.v11i2.4251

Laksmi, A. C., \& Febrian, R. S. (2018). Faktor-faktor penentu tingkat pemahaman mahasiswa akuntansi. Jurnal Akuntansi \& Auditing Indonesia, 22(1), 25-35. https:// doi.org/10.20885/jaai.vol22.iss1.art3

Mardjono, E. S., \& Solikhan, B. (2014). Profesionalisme Akuntan Pendidik: Perspektif Atau Triger Kualitas Lulusan Akuntansi Di Era Masyarakat Ekonomi Asean. Journal of Accounting and Auditing, 11(1), 103-119. https:// doi.org/10.14710/jaa.v11i1.9701

Meilisa, F., \& Ludigdo, U. (2010). Persepsi Mahasiswa Akuntansi terhadap Etika Akuntan Pendidik di Jurusan Akuntansi Fakultas Ekonomi Universitas Brawijaya. Jurnal Akuntansi Multiparadigma, 223-238. https:// doi.org/10.18202/jamal.2010.08.7091

Mukmin, M. \& Wulansari, H. (2017). Akuntabilitas Kinerja Akuntan Pendidik Berdasarkan Kompetensi Akuntan dan Etika Profesional (Studi Empiris Pada Perguruan Tinggi Swasta di Bogor). Jurnal Akuinida, 3, 57-65.

Muliawat. (2012). Aspek keperilakuan dalam akuntansi keuangan. Bina Ekonomi, 16(2), 84-92.

Murniasih, N. S., \& Purnamawati, I. G. A. (2015). Analisis Perbedaan Persepsi Terkait Kompetensi Lulusan S1 Akuntansi UniversitasPendidikan Ganesha e-Journal Ak S1 Universitas Pendidikan Ganesha. E-Journal Ak S1 Universitas Pendidikan Ganesha, 3(1).

Nahartyo, E. (2016). Menghindari Krisis Legitimasi: Kebijakan Pendidikan Avoiding Crisis of Legitimacy: Accounting Education Policy From. Jurnal Pendidikan Akuntansi Indonesia, XIV(2).

Purnama, D., \& Azizah, S. N. (2019). Implementasi Sistem Keuangan Desa Berbasis Akuntansi Keperilakuan. Jurnal Kajian Akuntansi, 3(2), 160. https:// doi.org/10.33603/jka.v3i2.2606

Riczqi, T., Putri, S., \& Harto, P. (2012). Persepsi Mahasiswa Akuntansi Dan Akuntan Pendidik Terhadap Kompetensi Yang Dibutuhkan Lulusan Akuntansi. Diponegoro Journal of Accounting, 1(1), 861-869. 
Sarmigi, E., \& Andriadi, D. (2019). Analisis penerapan akuntansi keperilakuan terhadap mahasiswa akuntansi stie sakti alam kerinci 1,2. Jurnal Benefita, 4(November 2018), 51-69. https:/ / doi.org/10.22216/jbe.v4i1.3834

Sawitri, A. P. (2017). Peran Akuntan Pendidik dalam Meningkatkan Profesionalisme Calon Akuntan. 4(2), 146-155.

Suryanti, \& Arfah, E. A. (2019). Pengaruh Profesionalisme Akuntan Pendidik,. Atestasi Jurnal Ilmiah Akuntansi, 2(1), 1-10.

Syamsuddin. (2019). Determinan Pemahaman Mahasiswa Akuntansi di Perguruan Tinggi Negeri dan Swasta. ATESTASI: Jurnal Ilmiah Akuntansi, 2(2), 148-160.

Wibowo. (2014). Perilaku dalam Organisasi. Jakarta: Raja Grafindo Persada.

Wirianata, H. (2017). Kompetensi Mahasiswa Jurusan Akuntansi Dan Kesiapannya Dalam Menghadapi Dunia Kerja Era Masyarakat Ekonomi Asean (Mea ). Jurnal Ekonomi, 22(3). https://doi.org/10.24912/je.v22i3.278 